\title{
Design of personnel information systems using rapid application development method
}

\author{
Dini Destiani Siti Fatimah*, Asep Deddy Supriatna, and Rina Kurniawati \\ Sekolah Tinggi Teknologi Garut, Department of Informatics, J1. Mayor Syamsu No. 1, Garut, 44151, Indonesia
}

\begin{abstract}
Information system is a system that is interconnected and integrated with each other and aims to provide personnel information to support operations, management and decision-making functions within an organization. The purpose of this research is to build personnel information system with Rapid Application Development (RAD) method. The methodology used in this design is the RAD method which consists of identifying the objectives and information requirements, designing the system, building the system, and introducing the new system. This study is limited to the design stage only. The design result is a more effective and efficient employee information system design. The conclusion of this research is that the information system built with RAD method takes shorter time, but required good coordination between system designer with user.
\end{abstract}

\section{Introduction}

Technological devices are designed to enhance a quality of human's life [1], one of those which are enable efficiency and effectiveness in business process within a field of personnel management is information systems. Management information system is a system that manages data into information necessary to support the activities of an organization. Some government agencies have a manual and complicated personnel work system. This situation needs to be changed by applying a computerized system that is Personnel Information System [2-4]

Information systems is a combination of information technology utilizations and human activity upon a set of agreed procedures [5], generally is used to support management and operation [6]. Information system is an organized data process [7], Information system has a high level of flexibilities to develop and scalable [8]. The process begins with data recording derived from the activities of the organization until the resulting information. Information is needed to assist the organization's leadership in making decisions [9]. Information systems that can provide information about personnel is called the personnel information system.

Personnel information system is part of management information system [10]. Refers to several research, an information system has a high capability in decision making, the system has an accurate data accessibility [11], efficient run-time [12], high accuracy [13], and to support a proper decision [14], low cost [15], extended accessibility [16], intensify user knowledge [17], increase productivity [18], and provide a better data and information [19].

The design of information systems using one method of software engineering. Software engineering is an attempt of someone to design the most effective and efficient software. The design of information systems using one method of software engineering. Software engineering is an attempt of someone to design the most effective and efficient software. The development of software engineering method since 1960 up to now has different subject of the functional era, the era of scheduling, the era of financing, the era of quality and efficiency of design, even now in synergy with knowledge engineering. $[9,20]$ Software engineering has two approaches: conventional and object-oriented approaches. The conventional approach has three methods, namely Linear Sequential Model, Prototyping and Rapid Application Development (RAD) [21].

The purpose of this study is to design a personnel information system in the Community Empowerment and Village Government (BPMPD) Garut. This research uses $\mathrm{RAD}$ as its design method because the stages in RAD method are very clear and easy to follow. Another consideration is that design can run relatively faster because designers and users work together in the development stage. The design of personnel information system involves the design of the database, so that data to be processed available with the type and amount adequate. The accuracy of the database design has an impact on the system response time that satisfies the user. The design of the user interface is presented through a menu structure that guides the overall creation of system views. Recent research shows that RAD method has been successfully used in some application development, including application of Android-based about Indonesian domestic culture [22].

\footnotetext{
* Corresponding author: dini.dsf@sttgarut.ac.id
} 


\section{Method}

RAD is a linear sequential software development model that emphasizes a very short development cycle (Fig. 1.). A short time is an important limitation for this model. Rapid application development uses iterative (recurring) methods in developing the system. The first stage of RAD is the construction working model (work model) system. The work model is constructed at the beginning of the development stage with the aim of defining user needs. Working models are used sometimes as the basis for the design and implementation of the final system [23].

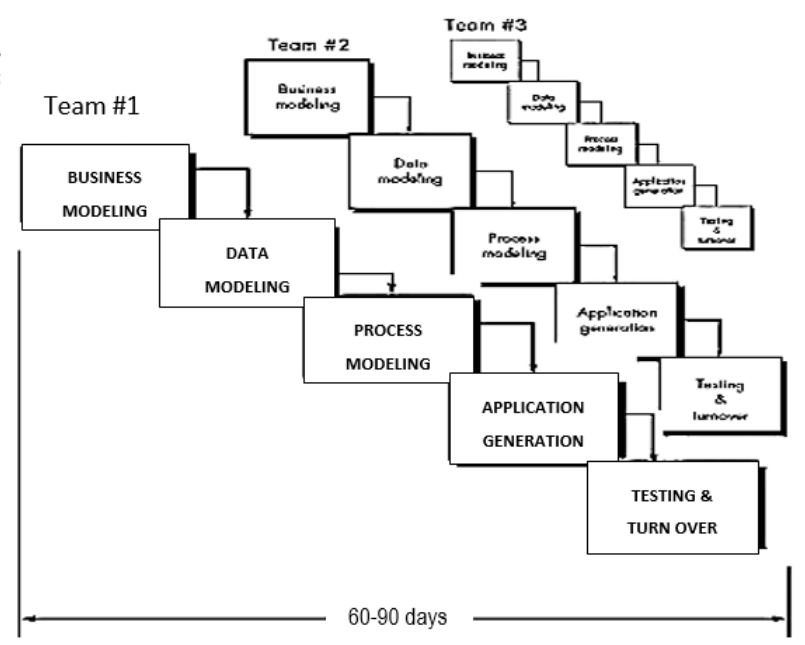

Fig. 1. Model RAD [23].

Fig. 1 shows the stages in RAD is Business Model, Data Modeling, Process Modeling, Application Generation, and the last is Testing and Turnover. The explanations of each stage are described as follows [23].

\subsection{Business modelling}

Modeling the flow of information between business functions. The resulting model should include: (1) the information that controls the business process; (2) the information it generates; (3) who generated the information; (4) where the information goes; (5) who processed it.

\subsection{Data modeling}

Filtering the flow of information that has been defined in the previous stage into a series of object data. Data object is selected because according to the needs of system development. Next each object is identified characteristics and relationships.

\subsection{Process modeling}

The transformation of the information flow defined in the data modeling phase becomes the necessary information flow for the implementation of a business function. The process is depicted and built to add, modify, delete, or retrieve a data object.

\subsection{Application generation}

RAD builds software using automated tools. Automated tools such as computers are used to facilitate the construction of software. RAD allows the reuse of existing program components or creates reusable components.

\subsection{Testing and turnover}

The RAD process emphasizes the use of existing program components. The number of proven program components can save the overall testing time. The new program components must be tested and all interfaces must be fully trained.

\section{Result and discussion}

Badan Pemberdayaan Masyarakat dan Pemerintahan Desa (BPMPD) or Community Empowerment Board and Village Government is one of the institutions in the system of local government, tasked with improving the process of development and empowerment of the village. BPMD Garut has employees who are in charge of empowering villagers in the Garut area, therefore the personnel management needs to be supported by computer-based information systems to be accessed by employees spread across 42 districts in Garut Regency. This section discusses the results of employment information system design BPMPD Garut built using RAD method.

\subsection{Business modelling}

Description of personnel process in BPMPD Garut on Fig.

2. consists of:

a. Registration of employee identity through resume form

b. Recording of attendance through the attendance form

c. Recapitulation of attendance in the form of attendance report.

d. Recapitulation of employee performance in the form of DP3 report (Document of Job Employment Implementation Evaluation).

e. Making a salary report based on employee data.

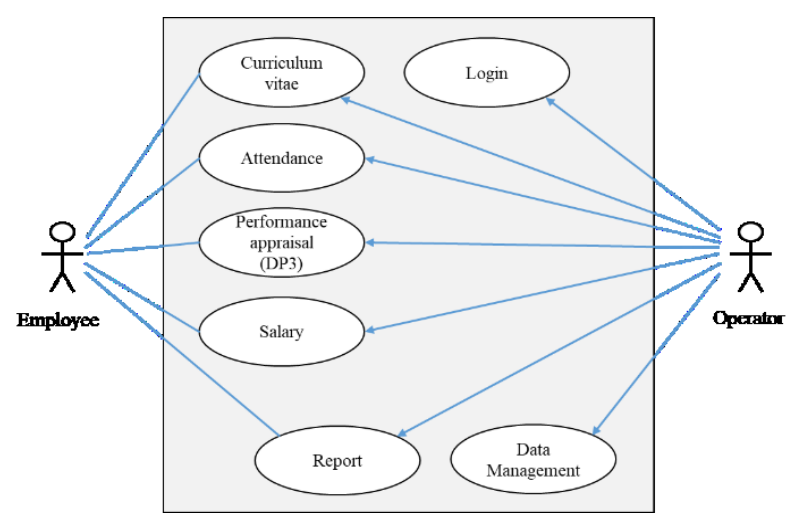

Fig. 2. Business Model of BPMPD Personnel Information System. 
Based on the description of the business process presented, can be identified documents required or produced. The document identification results are used to classify files that are grouped into master files, transaction files and report files.

\subsection{Data modelling}

This stage is done to reinforce and evaluate the identified documents of the business process. Employment data modeling in BPMPD using Entity Relationship Diagram (Fig. 3.). Based on this ERD can be identified relationship between employee with position and attendance to determine salary and performance of employee.

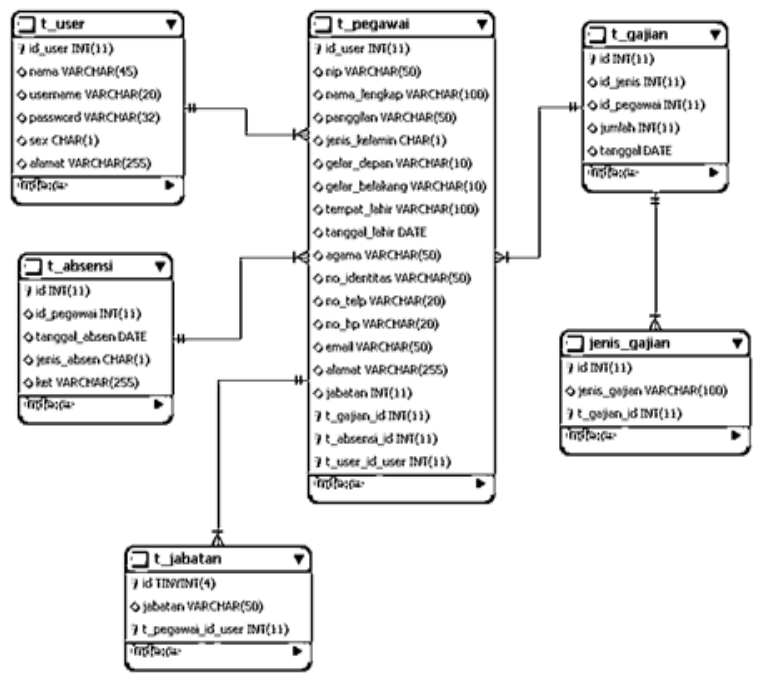

Fig. 3. ERD of BPMPD Personnel Information System.

Fig. 3 shows that employee salaries are determined by presence and position. Attendance represents the performance of employees, while the position represents the competence of employees.

\subsection{Process modelling}

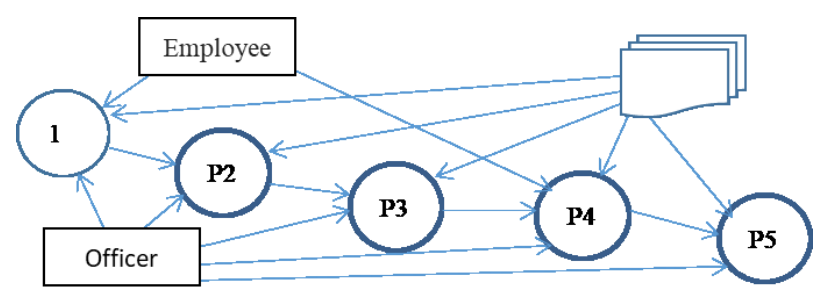

Fig. 4. Process Flow Diagram.

Caption Figure 4:

P1: Recording of employee data

P2: Recording of employee activity

P3: Recapitulation of employee data

P4: Recapitulation of employee activity data

P5: Report creation

Based on the diagram shown in Figure 4, the relevant documents in this system consist of employee data, employee activity data, employee data recapitulation, recapitulation of employee activity data and various employee reports such as attendance and DP3.

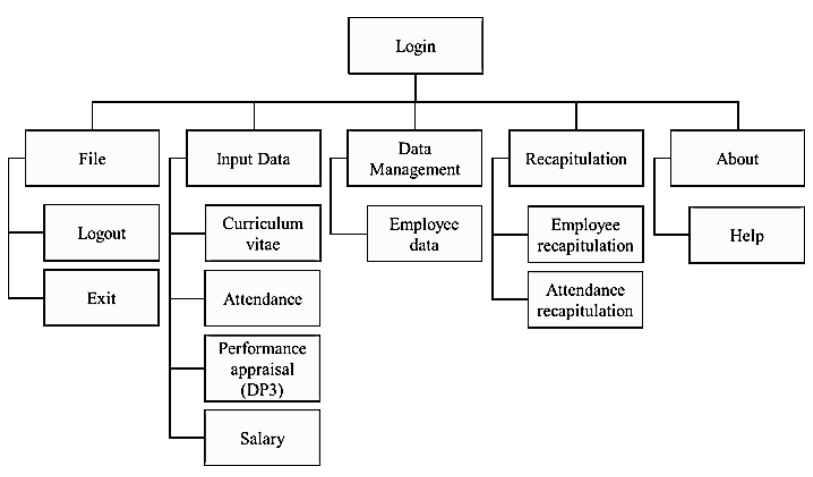

Fig. 5. Main Menu Structure of BPMPD PIS.

\subsection{Application Generation}

At this stage developed the design of menu structure (Figure 5). Menu structure is used to guide the design of information systems display, so that the information system employment built in accordance with the needs of personnel management in BPMPD.

\section{Conclusion}

Based on the design of personnel information system using RAD found a clear and continuous stages for the development needs of personnel management information system in BPMPD. Development of personnel information system can increase the need of providing information to support the performance and goals of the organization. The use of personnel information system development method using $\mathrm{RAD}$ can accelerate the process of system design. The structure of the menu is designed to suit the needs of business processes because the design of this system can be used to improve management performance and achievement of organizational goals. The advantages of the RAD method is the shorter usage time. This is due to two causes: first: the entire RAD stages by the designer and the user; second, the reduced test time due to the use of reusable program components.

\section{References}

1. M. A. Ramdhani, H. Aulawi, A. Ikhwana, and Y. Mauluddin, "Model of green technology adaptation in small and medium-sized tannery industry," J. Eng. Appl. Sci., vol. 12, no. 4, pp. 954-962, (2017)

2. T. Kurnia, D. Destiani, and A. D. Supriatna, "Perancangan Sistem Informasi Akademik Nilai Siswa Berbasis Web," J. Algoritm., vol. 9, no. 1, (2012)

3. R. Setiawan, "Perancangan Arsitektur Enterprise Untuk Perguruan Tinggi Swasta Menggunakan Togaf ADM,” J. Algoritm., vol. 13, no. 1, 2016.

4. M. S. Bachtiar and A. D. Supriatna, "Pengembangan Sistem Informasi Penjualan Batu Akik Market Place Kiara Gemstone,” J. Algoritm., vol. 13, no. 1, (2016) 
5. A. Pamoragung, K. Suryadi, and M. A. Ramdhani, "Enhancing the implementation of e-Government in indonesia through the high-quality of virtual community and knowledge portal," in Proceedings of the European Conference on e-Government, ECEG, pp. 341-348. (2006)

6. M. A. Ramdhani, Metodologi Penelitian untuk Riset Teknologi Informasi. Bandung: UIN Sunan Gunung Djati Bandung, (2013)

7. D. S. Maylawati, W. Darmalaksana, and M. A. Ramdhani, "Systematic Design of Expert System Using Unified Modelling Language," IOP Conf. Ser. Mater. Sci. Eng., vol. 288, no. 1, p. 12047, (2018)

8. H. Aulawi, M. A. Ramdhani, C. Slamet, H. Ainissyifa, and W. Darmalaksana, "Functional Need Analysis of Knowledge Portal Design in Higher Education Institution," Int. Soft Comput., vol. 12, no. 2, pp. 132-141, (2017)

9. E. Munawaroh, D. D. S. Fatimah, and A. D. Supriatna, "Perancangan Aplikasi Rekam Medis Klinik Bersalin Baiturrahman Menggunakan Metode Object Oriented," J. Algoritm., vol. 10, no. $1,(2014)$

10. F. Muhammad and A. Mulyani, "Pengembangan Sistem Informasi Penggajian di Pesantren Persis 99 Rancabango,” J. Algoritm., vol. 13, no. 1, (2016)

11. A. Taofik, N. Ismail, Y. A. Gerhana, K. Komarujaman, and M. A. Ramdhani, "Design of Smart System to Detect Ripeness of Tomato and Chili with New Approach in Data Acquisition," in IOP Conference Series: Materials Science and Engineering, vol. 288, no. 1, p. 12018. (2018)

12. C. Slamet, A. Rahman, A. Sutedi, W. Darmalaksana, M. A. Ramdhani, and D. S. Maylawati, "Social Media-Based Identifier for Natural Disaster," IOP Conf. Ser. Mater. Sci. Eng., vol. 288, no. 1, p. 12039 , (2018)

13. C. Slamet, R. Andrian, D. S. Maylawati, W. Darmalaksana, and M. A. Ramdhani, "Web Scraping and Naïve Bayes Classification for Job Search Engine," vol. 288, no. 1, pp. 1-7, (2018)

14. Y. A. Gerhana, W. B. Zulfikar, A. H. Ramdani, and M. A. Ramdhani, "Implementation of Nearest Neighbor using HSV to Identify Skin Disease," IOP Conf. Ser. Mater. Sci. Eng., vol. 288, no. 1, p. 0121531234567890 Implementation, (2018)

15. A. Rahman, C. Slamet, W. Darmalaksana, Y. A. Gerhana, and M. A. Ramdhani, "Expert System for Deciding a Solution of Mechanical Failure in a Car using Case-based Reasoning," IOP Conf. Ser. Mater. Sci. Eng., vol. 288, no. 1, p. 12011, (2018)

16. C. Slamet, A. Rahman, M. A. Ramdhani, and W. Darmalaksana, "Clustering the Verses of the Holy Qur'an Using K-Means Algorithm," Asian J. Inf. Technol., vol. 15, no. 24, pp. 5159-5162, (2016)

17. D. S. Maylawati, M. A. Ramdhani, W. B. Zulfikar, I. Taufik, and W. Darmalaksana, "Expert system for predicting the early pregnancy with disorders using artificial neural network," 2017 5th Int. Conf. Cyber IT Serv. Manag. CITSM 2017, (2017)

18. W. B. Zulfikar, Jumadi, P. K. Prasetyo, and M. A. Ramdhani, "Implementation of Mamdani Fuzzy
Method in Employee Promotion System," IOP Conf. Ser. Mater. Sci. Eng., vol. 288, no. 1, p. 12147, (2018)

19. D. S. Maylawati, M. A. Ramdhani, A. Rahman, and W. Darmalaksana, "Incremental technique with set of frequent word item sets for mining large Indonesian text data," 2017 5th Int. Conf. Cyber IT Serv. Manag. CITSM 2017, pp. 1-6, (2017)

20. G. J. Nalepa and a. J. Baumeister, Synergies Between Knowledge Engineering and Software Engineering., (Cham: . Springer, 2018)

21. C. Permana and R. Setiawan, "Pengembangan Aplikasi Pengolahan Nilai Siswa Berbasis Web di Sekolah Dasar Negeri," J. Algoritm., vol. 13, no. 1, (2016)

22. A. Muharom, R. Cahyana and a. Bunyamin, "Pengembangan Aplikasi Sunda menggunakan Metode Rapid Aplication Development (RAD)," Jurnal Algoritma, vol. 10, no. 1, pp. -, (2013)

23. R. S. Pressman, Software engineering: a practitioner's approach. (New York: Palgrave Macmillan, 2002) 